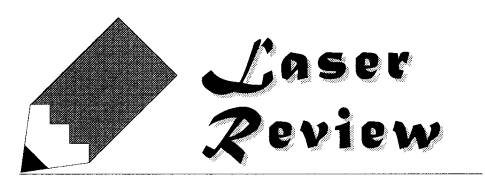

\title{
強レーザー場中の超高速分子ダイナミクスの理論
}

\author{
河野 裕彦 ${ }^{1}$, 中井 克典 ${ }^{1}$, 佐藤 幸男 ${ }^{2}$ \\ 1東北大学大学院 理学研究科 ( T980-8578 宮城県仙台市青葉区荒巻字青葉6-3) \\ 2アドバンスソフト (株)（†107-0052 東京都港区赤坂1-9-20）
}

\section{Theoretical Investigation of Ultrafast Dynamics of Molecules in Intense Laser Fields}

\author{
Hirohiko KONO, ${ }^{1}$ Katsunori NAKAI, ${ }^{1}$ and Yukio SATO ${ }^{2}$ \\ ${ }^{1}$ Department of Chemistry, Graduate School of Science, Tohoku University, Aramaki, Aoba-ku, Sendai, Miyagi $980-8578$ \\ ${ }^{2}$ Advancesoft Corporation, 1-9-20 Akasaka, Minato-ku, Tokyo 107-0052
}

(Received July 24, 2007)

\begin{abstract}
We developed a time-dependent (TD) adiabatic state approach to investigate the electronic and nuclear dynamics of molecules in intense laser fields. We applied the approach to reveal the mechanism of the selective dissociation of C-O and C-C bonds of ethanol by intense near-infrared (IR) laser pulses. The results indicate that field-induced nonadiabatic transition plays a decisive role in the reaction of molecules in intense laser fields. We also investigated the stability of highly charged $\mathrm{C}_{60}$ cations produced with an ultrashort near-IR pulse. The effects of nonlinear interactions with pulses are taken into account by combining classical molecular dynamics with the TD adiabatic state approach. The results indicate that large-amplitude vibration with energy of $>30 \mathrm{eV}$ is induced in the delocalized $h_{g}(1)$-like mode of $\mathrm{C}_{60}$ or $\mathrm{C}_{60}^{z+}$. The vibrational energy deposited and mode selectivity can be controlled by a pulse train, i.e., by changing the intervals between pulses.
\end{abstract}

Key Words: Intense laser field, Ab initio molecular dynamics, Fullerene, Nonadiabatic transition

\section{1.はじめに}

超短高強度レーザーの出現は，物質加工などの応用分 野のみならず，原子・分子科学などの基礎科学にも新た なインパクトをもたらした11). 水素原子の $1 s$ 軌道の電子が 原子核から受ける引力は $5.1 \times 10^{11} \mathrm{~V} / \mathrm{m}$ の電場に対応し， 光強度に換算すると, $3.5 \times 10^{16} \mathrm{~W} / \mathrm{cm}^{2}$ となる. $10^{13} \mathrm{~W} / \mathrm{cm}^{2}$ 以上の光の場は, クーロン力と拮抗する強い力を電子に 及ぼす。強い光によって分子中の電子は大きく摇すぶら れ，原子核が感じる有効ポテンシャルが変わってくる. それに伴い, 分子の構造変化が進み, 結合が切れる(解 離), あるいは, 結合の組み替え(化学反応)が起こる.

このような強いレーザー光は，結合選択的な分子反応 の制御の道具としても大きな可能性を秘めている2,3). 一 般に, 分子に注入されたエネルギーは, 振動エネルギー再 分配過程 (Intramolecular Vibrational Energy Redistribution, IVR $)^{4)}$ によって，複数の結合にピコ秒程度で急速に流れ 込むため, 光励起によって結合選択的な反応を起こすこ とは困難とされている，強レーザー場中では，多光子吸 収や大きなシュタルクシフトの効果によって, 弱い光の 場合に比べて，さらに多くの反応チャンネルが開く．し かしながら, 強度が大きいと, パルス長を変えることや
光の位相の制御による波形整形によって, 電子状態を短時 間で大規模に“操作”しポテンシャル面を変形させて, IVR の“方向”を調整できる可能性がある. 実際, 遺伝的アルゴ リズム (Genetic Algorithm，GA)に基づいた波形整形技術を 用いて, Gerber ${ }^{2}$ やLevis ${ }^{3)}$ ら $10^{13} \mathrm{~W} / \mathrm{cm}^{2}$ 程度の光で多原 子分子の分解反応を起こし, 各種解離生成物の収率や分岐 比を大きく変えることに成功した。 これらの実験は, 高強 度領域でも, 光位相が化学反応の制御因子として重要であ ることを示している.

このようにGAを用いた方法は沉用的であるが，制御の 機構についてはわからない場合が多い.さらに選択性を上 げるためには，どのような波長領域での制御が最も効率的 かなど多くの基本的な問題に答える必要がある，また，ど の親イオンの段階で反応が起こっているかを特定すること は，容易でない場合が多い。中島5)や板倉6)らは，一般 に，入射光の振動数が 1 価のカチオンの吸収帯に入ってい れば，イオン化よりも分解が起こると主張しているが，例 外もある7). イオン化と分解過程の競合を制御する方法を 確立することは, 分析化学的な応用面からも注目される.

以上のように, 分子制御の機構に関しては未知の部分が 多く, 新たな分子制御のシナリオを構築していく上で理論 が果たすべき役割は大きい. 本稿では, 強レーザー場中の 
分子の動力学理論の現状を, 著者らの研究を中心に解説 する。

\section{2. $\mathrm{H}_{2}+$ と $\mathrm{H}_{2}$ のダイナミクス}

研究代表者らは, 強レーザー場中の分子の電子や核の 動きが，レーザー電場 $\boldsymbol{\varepsilon}(t)$ の変化に追従する時間依存断熱 電子状態 $(\varepsilon(t)$ との双極子相互作用も含めた瞬間的な電子 ハミルトニアンの固有関数) とそれらの間のレーザー場誘 起非断熱遷移の確率を使って説明できることを, $\mathrm{H}_{2}{ }^{+} \mathrm{P}_{2}$ を例として明らかにしてきた8-11).

分子軸と光の偏光方向が平行であると仮定し, 電子座 標 $\{\boldsymbol{r}\}$ に加え, 分子振動を表す核間の距離 $R$ も量子力学的変 数として扱う。開発したクーロン系に対する時間依存 Schrödinger方程式の数值的解法を用いて, 電子と分子振動 の全体を記述した厳密な波動関数 $|\Psi(\boldsymbol{r}, R, t)\rangle$ を求め た10-12).

照射する光の波長 $\lambda$ を $760 \mathrm{~nm}$, 光強度 $I$ を $5 \times 10^{14} \mathrm{~W} / \mathrm{cm}^{2}$ とした場合の結果を説明する9,13,14). $\mathrm{H}_{2}$ からの垂直イオン 化により $\mathrm{H}_{2}{ }^{+}$の基底電子状態 $1 s \sigma_{\mathrm{g}}$ が生成し, この時刻 $t=0$ での初期状態の振動波動関数は $\mathrm{H}_{2}$ の最低振動状態 (平衡核 間距離 $=0.7 \AA)$ とする. $\mathrm{H}_{2}{ }^{+}$と $\mathrm{H}_{2}$ の平衡核間距離が違うた め, 垂直イオン化直後から $\mathrm{H}_{2}{ }^{+}$の核間距離が伸びる. $t=5$ fsでR=2 程度まで伸び，急激にイオン化が始まる。そ の後, さらに有効ポテンシャルが光の力によってひず み, 核間距離が伸びていく. $t=10 \mathrm{fs}$ で50\%程度イオン化 する.

イオン化の確率はRに大きく依存し, 平衡核間距離に比 べて, $R=2-5 \AA$ の中間領域ではイオン化速度が3-4杵増大 する9,13,14).この平衡核間距離より2倍程度の長い核間距離 でイオン化が促進される現象は増強イオン化 (Enhanced Ionization) と呼ばれ, 一般に多原子分子でも起こり, 強 レーザー光によって分子が多価イオンになる主要な機構 と考えられている15).

全波動関数の電子状態の成分は電子の連続状態 (イオン 化成分) と2つの核の周辺に大きな存在確率を持つ束縛電 子状態からなる. 束縛電子状態の主成分は $1 s \sigma_{\mathrm{g}}$ と $1 s \sigma_{\mathrm{u}}$ の最 も低い2つの電子状態である. 束縛されている電子は, $R<$

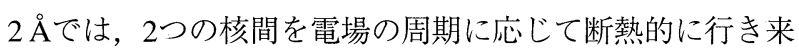
するが， $R>2$ Aの伸びた領域では，電子が核間を行き来 することができなくなり，どちらかの核に電子が局在す る9,13,14) (非断熱遷移領域あるいは透熱領域 16,17$)$ ).

イオン化直前までの核の動きは上記の束縛電子状態に よって決まっている.レーザー電場の振動サイクルに応 じて束縛された電子の状態が変わるが, 光の一周期が数fs と非常に短いにもかかわらず，Rが短いところでは電場の 時間変化に断熱的に追従している。このような状態は, ある時刻 $t$ における電場 $\boldsymbol{\varepsilon}(t)$ と分子中の荷電粒子(電子と核) との電気双極子相互作用を含んだ瞬間電子ハミルトニア ンの固有関数で定義することができ, 時間依存断熱状態 と呼ばれている13,14,18).

$\mathrm{H}_{2}+$ の場合は, 一番低い2つの束縛電子状態 $1 s \sigma_{\mathrm{g}}$ と $1 s \sigma_{\mathrm{u}}$ を 基底として $H(R, t)$ を対角化すると, $2 つ$ 固有関数, つま
り, 2 つの時間依存断熱状態と (電子の座標は省略), 及 び，その対応する固有值 $E_{1}(R, t)$ と $E_{2}(R, t)$ を得る ${ }^{8,9,13,14)}$.

$$
\begin{aligned}
& E_{2,1}(R, t)=\frac{1}{2}\left[E_{\mathrm{g}}(R)+E_{\mathrm{u}}(R) \pm \sqrt{\Delta E_{\mathrm{ug}}^{2}+4|\langle g|z| u\rangle \varepsilon(t)|^{2}}\right] \\
& \simeq \frac{1}{2}\left[E_{\mathrm{g}}(R)+E_{\mathrm{u}}(R) \pm R|\varepsilon(t)|\right](R>>1 \AA)
\end{aligned}
$$

ここで, すべての量は原子単位であり, $E_{\mathrm{g}}(R)$ と $E_{\mathrm{u}}(R)$ は, Fig. 1の破線で示されている $1 s \sigma_{\mathrm{g}}$ と $1 s \sigma_{\mathrm{u}}$ の断熱エネル ギーである. $\langle g|z| u\rangle$ は両状態間の遷移双極子モーメント である. $\mathrm{H}_{2}{ }^{+}$電子が感じるポテンシャルは一つ一つのプ ロトンの周りに深い井戸を持つ. $\varepsilon(t) \neq 0$ の瞬間は, 一つ の井戸の静電的なポテンシャルは下がり, 他方のポテン シャルは上がる。 $|1(R, t)\rangle$ と $|2(R, t)\rangle$ はそれぞれ低い井戸 と高い井戸に電子が局在した状態である。従って, 式 (1) で与えられるように, $E_{1}(R, t)$ と $E_{2}(R, t)$ はFig. 1 の実線の ように $R$ の関数として変化する. $\varepsilon(t)=0$ の瞬間は, $|1(R, t)\rangle$ と $|2(R, t)\rangle$ はそれぞれ $1 s \sigma_{\mathrm{g}}$ と $1 s \sigma_{\mathrm{u}}$ に一致する.

イオン化も含んた電子と分子振動の全体を記述した $|\Psi(r, R, t)\rangle$ を, $|1(R, t)\rangle$ と $|2(R, t)\rangle$ に射影して得られる係数 $\chi_{1}(R, t)$ と $\chi_{2}(R, t)$ が, 2つの時間依存のポテンシャル面 $E_{1}$ $(R, t)$ と $E_{2}(R, t)$ の上を動く振動波動関数を表すことにな る $^{9,13,14)}$. 得られた $\chi_{1}(R, t)$ と $\chi_{2}(R, t)$ を用いると, $\mathrm{H}_{2}{ }^{+}$の夕゙ イナミクスを以下のように解釈することができる. $\varepsilon(t)$ が 0から大きくなるにつれて, $E_{1}(R, t)$ のポテンシャル面のエ ネルギーが下がり， $E_{2}(R, t)$ が上がる．電場が0に戻ってく

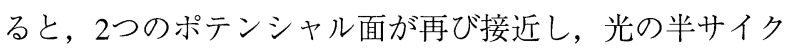
ル周期で, ポテンシャル面間のavoided crossing (反発交差 あるいは交差回避)が起こる．2つのポテンシャル面があ る程度接近すると, $E_{1}(R, t)$ 上の $\chi_{1}(R, t)$ の一部が $E_{2}(R, t)$ 面へ乗り移り， $\chi_{2}(R, t)$ 成分が生じる(逆も起こり得る).

これは光電場誘起の非断熱遷移と呼ばれ, 電子の局在に

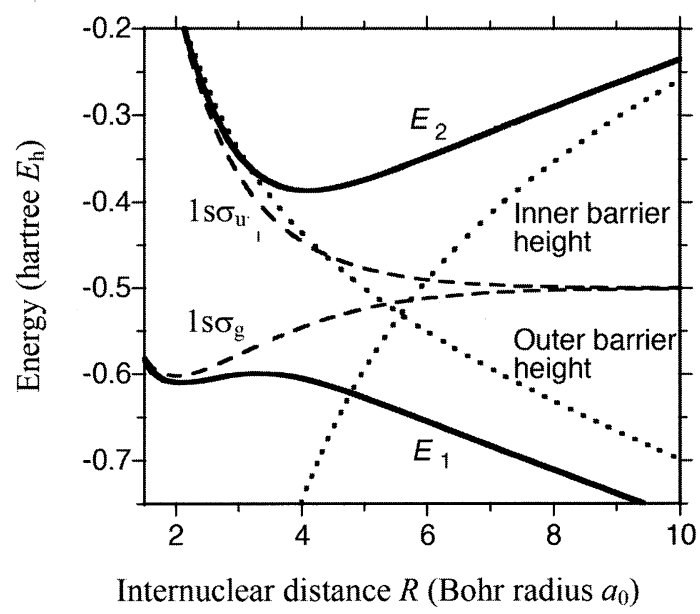

Fig. 1 Potential energies $E_{1}(R, t)$ and $E_{2}(R, t)$ of the lowest two time-dependent adiabatic states $|1(R, t)\rangle$ and $|2(R, t)\rangle$ of $\mathrm{H}_{2}{ }^{+}$(denoted by solid lines) at 0.053 $E_{\mathrm{h}} / e a_{0}$, i.e., at light intensity $I=10^{14} \mathrm{~W} / \mathrm{cm}^{2}$ as a function of $R$. The broken lines denote the BornOppenheimer potential of $1 s \sigma_{\mathrm{g}}$ and $1 s \sigma_{\mathrm{u}}$. The dotted lines denote the heights of the inner and outer barriers for tunnel ionization. The internuclear repulsion $1 / R$ is included in the energy. 
対応している. $R$ の長いところでは $(R>2 \AA)$, 反発交差の エネルギーギャップが小さくなるので, 光電場誘起非断 熱遷移の確率が大きくなる。このように生成した $|2(R, t)\rangle$ の状態からイオン化が起こることも $\chi_{2}(R, t)$ の減少から判 り，増強イオン化の機構を同定することができる. $|2(R, t)\rangle$ の電子波動関数が局在している高い井戸からイオ ン化が起こるためには，2つのポテンシャル井戸間の障壁 (Inner barrier) と低い井戸の外側にある障壁 (Outer barrier) を電子が抜けていく必要がある。 $R=4-10 a_{0}(2-5 \AA)$ の領 域で, $E_{2}(R, t)$ がFig. 1 の点線で示された両障壁より高いこ とから，この領域で $|2(R, t)\rangle$ からイオン化しやすいことが わかる ${ }^{19)}$.この障壁越えイオン化では, 電子波動関数の 10-20\%が光電場の半周期の間に連続状態に移る.

多電子系のプロトタイプと見なせる $\mathrm{H}_{2}$ でも, 全系の波 動関数を時間依存断熱状態に射影して, 光サイクルの半 周期 ( 1.3 fs) ごとに局在イオン結合性配置 $\mathrm{H}^{+} \mathrm{H}^{-}$と $\mathrm{H}^{-} \mathrm{H}^{+}$が 交互に生成し，これらの配置から電子間反発によって増 強イオン化が起こることを明らかにした ${ }^{10,11)}$.

\section{3. 時間依存断熱状態法}

時間依存断熱状態を基底とした取扱いは，上記のよう な解析だけではなく, 一般の多原子分子の振動 (反応) ダイ ナミクスの記述にも適用できる13,14,18). 静電場 $\varepsilon(t)$ 中の多 原子分子の瞬間電子ハミルトニアンの固有值問題を分子 軌道法や密度汎関数を用いて解いて，時間依存断熱状態 $\left\{\left|n\left(\left\{R_{j}\right\}, t\right)\right\rangle, n=1,2, \cdots\right\}$ とエネルギー $\left\{E_{n}\left(\left\{R_{j}\right\}, t\right)\right\}$ を求め る.ここで， $R_{j}$ は複数の核座標あるいは分子内座標の集ま りを表している。電子と核の全系の波動関数 $\left|\Psi\left(\left\{r_{j}\right\},\left\{R_{j}\right\}, t\right)\right\rangle$ を次のように $N$ 個の時間依存断熱状態で展 開する。

$$
\left|\Psi\left(\left\{r_{j}\right\},\left\{R_{j}\right\}, t\right)\right\rangle=\sum_{n=1}^{n} \chi_{n}\left(\left\{R_{j}\right\}, t\right)\left|n\left(\left\{R_{j}\right\}, t\right)\right\rangle
$$

この展開式を全系の時間依存Schrödinger方程式に代入すれ ば, $\left\{\chi_{n}\left(\left\{R_{j}\right\}, t\right)\right\}$ が従う時間依存結合方程式を導ける. 異 なった断熱状態 $\left|n\left(\left\{R_{j}\right\}, t\right)\right\rangle$ と $\left|n^{\prime}\left(\left\{R_{j}\right\}, t\right)\right\rangle$ との間は一般 に光電場誘起の非断熱遷移を引き起こす結合項 $\left\langle n(t)|\partial / \partial t| n^{\prime}(t)\right\rangle$ で結ばれている.このような結合項も両状 態間の電気双極子遷移モーメントから計算できる. 結合 方程式は数值的に解け, 各時間依存断熱状態の上の核波 束の動きが求まり，強いレーザー場中の振動波束ダイナ ミクスを求めることができる.

\section{4. 多原子分子への応用}

時間依存断熱状態法は多原子分子に適用可能であり, まず, $800 \mathrm{~nm}$ の光と相互作用する $\mathrm{CO}_{2}$ 分子に適用した ${ }^{18)}$. 2価カチオンの段階で，2つのC-O結合が同時対称的に伸び て屈曲する過程が存在することを見出した．結合が伸び ると増強イオン化が起こり，クーロン爆発を起こす。こ のような特異なダイナミクスを解明することによって, 山内ら 20)によって報告されているクーロン爆発直前のカ
チオンの構造を説明することができた.

ここではエタノール分子 $\mathrm{CH}_{3}-\mathrm{CH}_{2}-\mathrm{OH}$ の強レーザー光に よる解離について取り上げる，分子骨格のC-C結合とC-O 結合はほぼ同じ $3.5 \mathrm{eV}$ の解離エネルギーを持つが, $10^{14}$ $\mathrm{W} / \mathrm{cm}^{2}$ 程度の強度をもつ強レーザー光の場合, 短いパルス ではC-C結合がC-O結合に比べて圧倒的に切れやすいとい う実験結果が報告されている21,22)。チャーピングによって

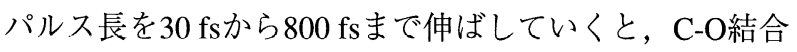
の解離確率 $P_{\mathrm{C}-\mathrm{O}}$ のC-C結合の解離確率 $P_{\mathrm{C}-\mathrm{C}}$ に対する相対比 $P_{\mathrm{C}-\mathrm{O}} / P_{\mathrm{C}-\mathrm{C}}$ は，1/10倍から $1 / 2$ まで約5倍増大する。この実験 結果は, 強レーザー光の単にパルス長を変えることに よっても解離などの化学反応を制御できる可能性を示し ている．著者等は時間依存断熱状態法をこのエタノール の骨格結合の解離の問題にも適用し, $P_{\mathrm{C}-\mathrm{O}} / P_{\mathrm{C}-\mathrm{C}}$ のパルス長 依存性がレーザー電場誘起の非断熱遷移と密接に関連し ていることを明らかにした．理論的取り扱いの結果を以 下にまとめる13,14)。

気相中のエタノール分子は空間にランダムに配向して いるので, C-C結合が光の偏光方向と平行な配置となって いる場合と, C-O結合が光の偏光方向に平行な配置となっ ている場合の2つを考える．前者は，C-C結合が最も切れ やすい配置で, 後者はC-O結合が最も切れやすい配置であ る。時間依存断熱状態法を適用して, 前者の配置におい てC-C結合が切れる確率と, 後者の配置においてC-O結合 が切れる確率とを比べる。

通常, 中性の分子では, 大きな構造変化が起こる前に イオン化し，エタノールの場合も同じである。従って， まず1価のエタノールカチオンにおいて, 解離のダイナミ クスに注目する。1価カチオンのポテンシャルをC-C結合 の長さの関数としてFig. 2 (a)にプロットした (C-C結合が 偏光方向に平行になっている配置). レーザー電場 $\varepsilon(t)$ が かかると, 光強度が増すにつれ, 時間依存断熱状態は次 第に大きなシュタルクシフトを呈するようになる. $\varepsilon(t)<$ 0の瞬間は(電場の向きは中央のC原子から末端のC原子に 向いている), Fig. 2 (b)に示されているように, ポテン シャル間に反発交差が起こる， $\mathrm{H}_{2}{ }^{+}$の場合と同じように交 差があると, 別の断熱面に乗り移るとことが起こり，そ の後の振動ダイナミクスは全く異なったものとなる.

実際にどのように核が動いているかをFig. 3に示す．縦 軸がC-C結合の距離で, 横軸が時間を指している. 最も工 ネルギーの低い2つの断熱状態に対応する2つの振動波束 だけを示している。まず，一番エネルギーが低い断熱状 態の核振動波束が，C-C結合間の平衡核間距離 $R_{\mathrm{c}-\mathrm{c}}^{0}=1.5$ Å辺りから徐々に伸びていく. ポテンシャル反発交差が起 こるC-C結合距離 $R_{\mathrm{c}-\mathrm{c}}$ が1.8 Å辺りに振動波束が近づくと, 上の断熱状態に振動波束が移り，そのような高い時間依 存断熱状態を経由し，C-C結合が解離することが分かる.

一方, C-O結合解離について調べると, やはり反発交差 があるが, 平衡核間距離とこの交差点との核間距離差が C-C結合に沿った場合に比べて 0.5 Åほど長くなる。つま り, 解離が促進される交差点に到達するに要する時間が C-C結合解離の場合に比べて長くなる. 従って, $30 \mathrm{fs}$ 程度 の短いパルスでは, C-O結合は相対的に切れ難く, この理 


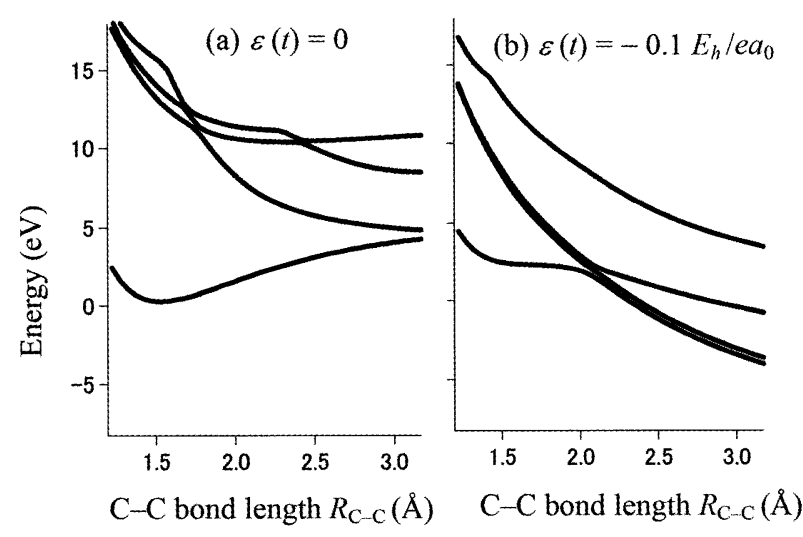

Fig. 2 Adiabatic potentials of lowest four adiabatic states (A"'-symmetry of the point group $C_{s}$ ) of $\mathrm{C}_{2} \mathrm{H}_{5} \mathrm{OH}^{+}$ as a function of $R_{\mathrm{C}-\mathrm{C}}$. The polarization direction of $\varepsilon(t)$ is assumed to be parallel to the $\mathrm{C}-\mathrm{C}$ bond axis. The field strength in each panel is chosen as follows: (a) $\varepsilon(t)=0$ and (b) $\varepsilon(t)=-0.1 E_{\mathrm{h}} / e a_{0}$. The value of $\varepsilon(t)$ is chosen to be positive when the field vector points from the end $\mathrm{C}$ atom to the middle $\mathrm{C}$ atom. The lowest three adiabatic states cross each other around $R_{\mathrm{C}-\mathrm{C}}=2.0 \AA$ when $\varepsilon(t)<0$, as shown in (b): Field-induced avoided crossings occur in a range not far away from the equilibrium C-C distance $(\sim 1.5 \AA)$.

論的考察は報告されている実験結果に一致する。また， $P_{\mathrm{C}-\mathrm{O}} / P_{\mathrm{C}-\mathrm{C}}$ がチャープ率の正負には依存せず，パルス長だけ に依存するという点においても実験結果と合っている.

しかしながら，実験では $P_{\mathrm{C}-\mathrm{O}} / P_{\mathrm{C}-\mathrm{C}}$ はパルス長とともに増 え，パルス長が800 fsあたりから飽和して一定値をとる が，上記の理論的取り扱いでは，200 fsでほぼ横ばいと なってしまう。これは，それぞれの結合を独立に扱った 簡単な一自由度モデルを使っているためであり，実験よ り1/5程度短い時間スケールで結合が切れてしまうことに 起因している。実際，この解離に要する時間は，他の振 動モードとの結合を組み込むことによって長くなる(例え ば, C-O-Hの変角振動を加えると, $P_{\mathrm{C}-\mathrm{O}} / P_{\mathrm{C}-\mathrm{C}}$ は $400 \mathrm{fs}$ で飽 和する).このことは, 直接レーザー光で励起された振動 モードと他の振動モードとの間のIVRを考慮することが多 原子分子ダイナミクスの定量的な議論には欠かせないこ とを示している。

\section{5. $\mathrm{C}_{60}$ の光誘起の振動・解離ダイナミクス}

$\mathrm{C}_{60}$ に $800 \mathrm{~nm}$ の強い光を照射すると, +5 価あたりまでの 親イオンに加えて, $\mathrm{C}_{60}$ から $\mathrm{C}_{2}$ 単位で炭素が脱離したフラ グメントカチオン $\mathrm{C}_{60-2 n}^{z+}$ も検出される23). 一方, Corkum らは, 波長 $1800 \mathrm{~nm}$ (パルス長70 fs, 強度 $10^{15} \mathrm{~W} / \mathrm{cm}^{2}$ ) の長波長の光を用いて, + 12価までの多価親カチオン $\mathrm{C}_{60}^{z+}$ を飛行型質量分析器 $(\mathrm{TOF})$ で検出した ${ }^{24)}$ 。 その際 $\mathrm{C}_{60-2 n}^{2+}$ な どのフラグメントはほとんど検出されなかった。一般 に，大きな分子では電子緩和やIVRがサブピコ秒のオー ダーで速く, 光制御が困難と考えられている。ここで は， $\mathrm{C}_{60}^{z+}$ 多価カチオンの安定性に関する理論的取り扱いを 概説し， $\mathrm{C}_{60}$ の様な大きな分子の強レーザー光による振 動・解離ダイナミクスの制御可能性について考察する.

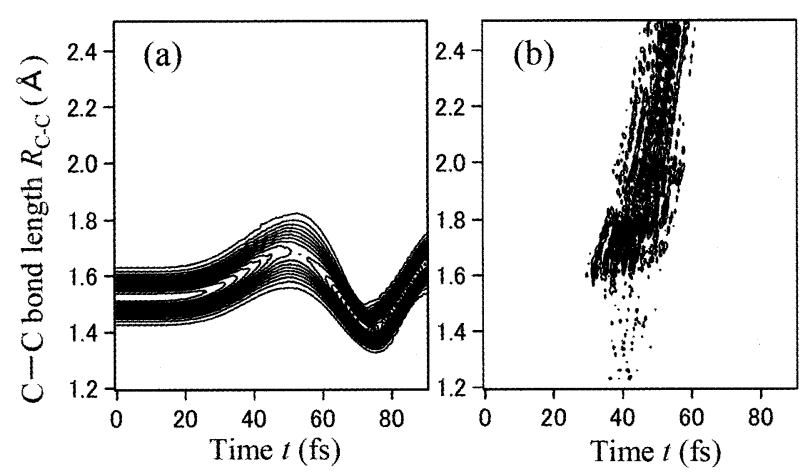

Fig. 3 C-C bond wave packets for the lowest two A"-symmetry adiabatic states $|1\rangle$ and $|2\rangle$ in a near-IR field of $\omega=0.0574 E_{\mathrm{h}} / \hbar(\lambda=795 \mathrm{~nm}):(\mathrm{a})\left|\chi_{1}\left(R_{\mathrm{C}-\mathrm{C}}, t\right)\right|^{2}$ and (b) $\left|\chi_{2}\left(R_{\mathrm{C}-\mathrm{C}}, t\right)\right|^{2}$. The pulse envelope has the following parameters: peak strength $f_{0}=0.12 E_{\mathrm{h}} / \hbar$ $\left(5.0 \times 10^{14} \mathrm{~W} / \mathrm{cm}^{2}\right)$ and pulse length $T_{\mathrm{p}}=75 \mathrm{fs}$. The initial state is the lowest vibrational state of the fieldfree ground electronic state of $\mathrm{C}_{2} \mathrm{H}_{5} \mathrm{OH}^{+}$. The wave packet $\chi_{1}\left(R_{\mathrm{C}-\mathrm{C}}, t\right)$ ramifies to the upper adiabatic states at $R_{\mathrm{C}-\mathrm{C}} \approx 1.8 \AA$ because of field-induced nonadiabatic transitions near the pulse peak. Field-induced nonadiabatic transitions at $R_{\mathrm{C}-\mathrm{C}} \approx 1.8 \AA$ occur only when $\varepsilon(t)<0$ (i.e., when field-induced avoided crossings occur). Once transferred to the upper adiabatic states, dissociation is promoted because the potentials of the upper adiabatic states averaged over one-optical cycle are dissociative.

$\mathrm{C}_{60}$ の様な大きな分子のダイナミクスは光との相互作用 を取り込んだ多自由度の分子場の上で議論しなければな らないが，まず， $\mathrm{C}_{60}^{2+}$ カチオンが何価まで安定構造を持っ ているかを調べる必要がある。密度汎関数法 (B3LYP or UB3LYP/ 6-31G (d))を用いて, 安定構造を探索し, 分子振 動解析によって+14価までの多価カチオン親分子が安定な 分子構造を持つことを確認した25,26). $\mathrm{C}_{60}^{14+}$ まで安定構造が 存在するのは，すべての結合がネットワークでつながっ ていること (中性 $\mathrm{C}_{60}$ では $\mathrm{C}_{2}$ 脱離の解離エネルギー $D(z)$ が イオン化エネルギーより高いという特異な性質を持つ) と 高い対称性のため電荷が各炭素原子にほぼ均等に配分さ れ， $\mathrm{C}_{60}^{z+}$ の特定の結合にクーロン反発エネルギーが局在し ないことによる。

次に, $1800 \mathrm{~nm}$ 励起の場合は, $800 \mathrm{~nm}$ 励起と比較すると 励起電子状態が生成する確率が一桁以上減少するので, 多光子吸収による励起電子状態経由のイオン化や解離は 無視できるとする。この条件の下で解離に使われ得る余 剰振動工ネルギーは，イオン化に伴って $\mathrm{C}_{60}^{2+}$ カチオンが得 る分子振動エネルギー $\Delta E_{\mathrm{vib}}(z)$ と熱エネルギー $E_{\mathrm{T}}(800 \mathrm{~K}$ の 条件で $5 \mathrm{eV}$ 程度)の和である．核が動く前にトンネルイオ ン化あるいは障壁越えイオン化が起こるとすると， $\Delta E_{\mathrm{vib}}$ (z) は $\mathrm{C}_{60}$ からの垂直遷移イオン化ポテンシャルと断熱遷移 イオン化ポテンシャルの差 $\Delta E_{\mathrm{p}}(z)$ と見なせる. $\Delta E_{\mathrm{p}}(z)$ と ともに，価数 $z$ 各カチオンの段階での $E_{\mathrm{T}}+\Delta E_{\mathrm{p}}(z)$ を Fig. 4に示した. $z>10$ の場合, $E_{\mathrm{T}}+\Delta E_{\mathrm{p}}(z)$ は急激に増大するの に対して, $D(z)$ は急激に減少し27)， $\mathrm{C}_{60}^{z+}$ の安定性が急激に 低下する。

以上のデータなどを使って統計的な解離の速度を見積 
もることができるRice-Ramsperger- Kassel-Marcus理論 ${ }^{28)}$ か ら見積もった寿命は，11，12，13価の親カチオンに対し て，それぞれ， $1 \mathrm{~s}, 1 \mu \mathrm{s}, 100 \mathrm{ps}$ のオーダーであり， $\mathrm{C}_{60}^{12+}$ までTOFで検出された実験結果を裏付けることができ

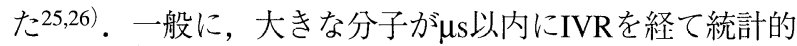
に解離するためには，余剰振動エネルギー $E_{\mathrm{T}}+\Delta E_{\mathrm{p}}(z)$ が $D(z)$ とキネティックシフトと呼ばれるエネルギーS $(z)^{29)}$ の和より大きくなければならない. $\mathrm{C}_{60}^{z+}$ の場合, $z=0-3$ に 対して $\mathrm{S}(z)=30-25 \mathrm{eV}$ もる $(\mathrm{S}(z=12) \sim 4 \mathrm{eV})^{23,29,30)}$.

次に，高強度近赤外光によって， $\mathrm{C}_{60}^{z+}$ のどの分子振動 モードにどの程度のエネルギーが注入されるかを第一原 理分子動力学計算によって調べた ${ }^{31)}$. 本手法では, 量子 力学的に計算した時間依存断熱状態の上で古典動力学的 にすべての核を動かして，古典的ではあるがすべての振

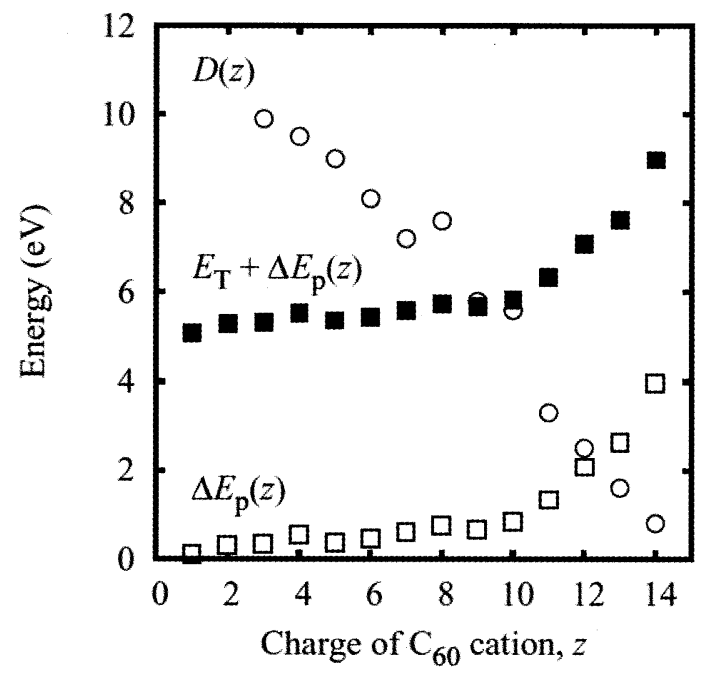

Fig. 4 Variation of energies relevant to the stability of $\mathrm{C}_{60}^{z+}$ : ( $\square$ ) denotes the difference between the energy of $\mathrm{C}_{60}^{z+}$ at the equilibrium structure of $\mathrm{C}_{60}$ and the energy of $\mathrm{C}_{60}^{z+}$ at its equilibrium structure, i.e., $\Delta E_{\mathrm{p}}(z)$; (O) the lowest barrier for $\mathrm{C}_{2}$-loss dissociation, i.e., $D(z)^{27)} ;(\square)$ the sum of $\Delta E_{\mathrm{p}}(z)$ and the thermal energy $E_{\mathrm{T}}(\sim 5 \mathrm{eV})$.
動モードの間の結合を考慮する. Fig. 5 はパルス長 $T_{\mathrm{p}}=70$ fs, $\lambda=1800 \mathrm{~nm}$ (ピーク光強度 $\left.I_{\text {peak }}=7 \times 10^{14} \mathrm{~W} / \mathrm{cm}^{2}\right)$ の近 赤外光と相互作用する中性 $\mathrm{C}_{60}$ のスナップショットである (パルス振幅のピークを時刻の原点 $t=0$ とする). 動力学計 算に必要な時間依存断熱面はB $3 \mathrm{LYP} / 3-21 \mathrm{G}$ を使って求め た。このシミュレーションでは, 分子の電荷は変わらな いとしている，実際はイオン化するが，その効果を取り 达んでも下記の議論は定性的には変わらない.

$T_{\mathrm{p}}=70 \mathrm{fs}$ のパルスとの相互作用によって, 振動エネル ギーが $30 \mathrm{eV}$ 程度増える。 その $50 \%$ は偏長と扁平の構造変 化を繰り返す $h_{\mathrm{g}}(1)$ モードに局在し，このモードがおよそ 1000 量子も励起されていることになる $\left(a_{\mathrm{g}}(1)\right.$ モードには〜 $4 \mathrm{eV}$ ). 非線形的に大きく励起 (Impulsive Raman Excitation) される振動モードの条件は, その振動モード座標に沿っ て分極率が大きく変化し, 振動周期 $T_{\mathrm{vib}}$ の半分が $T_{\mathrm{p}}$ 程度の 場合である. $h_{\mathrm{g}}(1)$ モードの周期は $T_{\mathrm{vib}}=125 \mathrm{fs}$ であり, $T_{\mathrm{p}}$ $=70 \mathrm{fs}$ に対して, $T_{\mathrm{p}} \approx T_{\mathrm{vib}} / 2$ が確かに成り立っている. $T_{\mathrm{p}}$ $=30 \mathrm{fs}$ の場合は, 注入されるエネルギーは $20 \mathrm{eV}$ となり, その内訳は $h_{\mathrm{g}}(1) に 8 \mathrm{eV}, a_{\mathrm{g}}(1)$ に $\mathrm{eV}$ である. $T_{\mathrm{p}}=70 \mathrm{fs}$ の場合と比べると， $67 \mathrm{fs}$ の短い周期を持つ $a_{\mathrm{g}}(1)$ モードが 相対的に励起されている.

$30 \mathrm{eV}$ も大きな振動エネルギーが $\mathrm{C}_{60}$ に注入されている が, ピコ秒の時間範囲では, 調和的な振動が続き解離は 起こらない。従って，大きな $\mathrm{C}_{60}$ に対しても，パルス列を 用いた振動ダイナミクス制御が可能である。一例とし て, 時間差 $\tau$ だけずらした $T_{\mathrm{p}}=30 \mathrm{fs}\left(I_{\text {peak }}=7 \times 10^{14} \mathrm{~W} / \mathrm{cm}^{2}\right.$, $\lambda=1800 \mathrm{~nm})$ のつのパルスを $\mathrm{C}_{60}$ に照射したシミュレー ションの結果を述べる. $\tau=125 \mathrm{fs}\left(h_{\mathrm{g}}(1)\right.$ モードの周期) と すると，2つのパルスとの相互作用によって振動エネル ギーは60 eV増え(単パルスの場合は〜 $20 \mathrm{eV}$ ), 主に $h_{\mathrm{g}}(1)$ モードが励起される. 他方, $\tau=201 \mathrm{fs}$ ように $a_{\mathrm{g}}(1)$ モー ドの周期 $(67 \mathrm{fs})$ の奇数倍とすると, 獲得するエネルギーは 単パルスの場合と変わらないが, 主要な励起モードを $h_{\mathrm{g}}$ (1) から $a_{\mathrm{g}}(1)$ に変えるモードスイッチングが可能であるこ とがわかった。
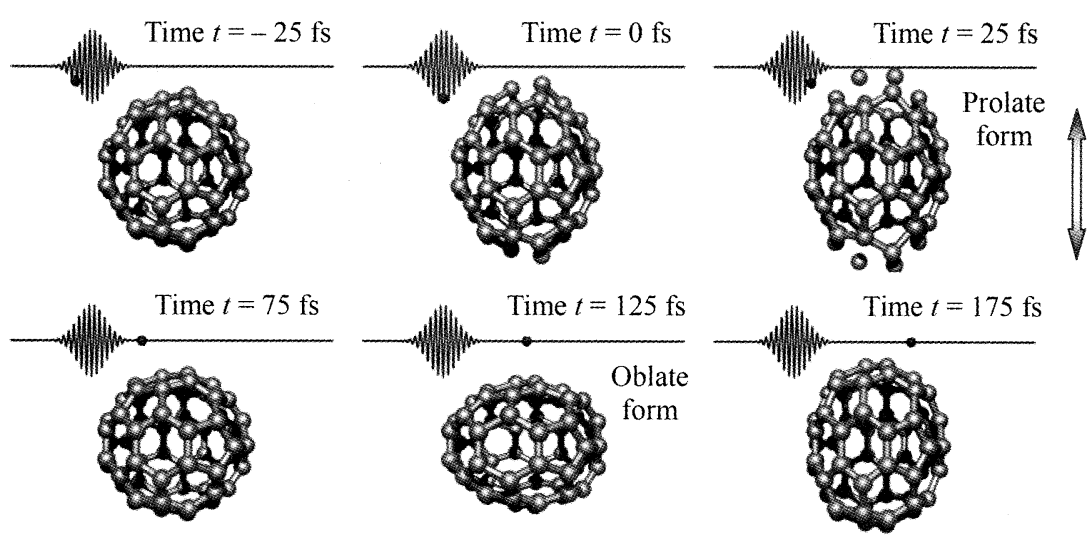

Fig. 5 Snapshots of the dynamics of the nuclei of $\mathrm{C}_{60}$ obtained by combining the time-dependent (TD) adiabatic state approach with a classical molecular dynamics method. The applied pulse is a Gaussian of $T_{\mathrm{p}}=70 \mathrm{fs}$ centered at time $t=0(\lambda=1800$ $\mathrm{nm}$ and peak intensity $I_{\text {peak }}=7 \times 10^{14} \mathrm{~W} / \mathrm{cm}^{2}$ ). All the nuclei are moved classically on the potential of the lowest TD adiabatic state. $\mathrm{C}_{60}$ acquires $\sim 30 \mathrm{eV}$ as a vibrational energy through impulsive Raman excitation. The $h_{g}(1)$ mode is mainly excited. The line with up and down arrows indicates the polarization direction of light. The temporal profile of the applied electric filed is sketched in the upper left corner of each snapshot of $\mathrm{C}_{60}$; a dot in the field profile denotes the field amplitude at $t$. 
$800 \mathrm{~nm}$ の波形整形パルスによっても， $\mathrm{C}_{60}$ の解離フラグ メントの生成量の割合を大きく変えうることがI. V. Hertel らによって報告されており ${ }^{32)}$, 多自由度の $\mathrm{C}_{60}$ でも光の位 相によって振動・解離ダイナミクスを制御できることが 明らかとなった。彼らの実験結果によれば，特定の解離 を促進する最適制御パルスが一定の時間間隔を持つパル ス列になっており, 初めに $h_{\mathrm{g}}(1) や a_{\mathrm{g}}(1)$ などの振動モード が大きく励起されている可能性が高い. 今後は， $h_{\mathrm{g}}(1)$ モードのような非局在振動に注入されたエネルギーが局 在的なC-C結合を切る解離過程に流れる機構や解離に要す る時間を明らかにし，制御機構を解明する必要がある。

\section{6. おわりに}

本稿では，時間依存断熱状態法に基づいたシミュレー ションの結果から, 強いレーザー光による分子制御の機 構について考察した. 分子の反応を決定づけるレーザー 電場誘起非断熱遷移の確率がパルス長や強度などによっ て大きく変わることが明らかとなり，この機構によって アルキルアルコールの選択的解離反応を定性的には説明 することができた. また， $\mathrm{C}_{60}$ においても波形整形パルス による解離制御が可能であるが，これは調和的分子振動 がピコ秒の領域で保持されているためであることが理論 的に明らかになった。

現実の制御実験の定量的説明や新たな分子制御シナリ オの構築に対しては，現状の理論の力量不足は否めない が，最近では光のスペクトル幅などの実験条件をより良 く反映した最適制御理論 ${ }^{33}$ ) (目的生成物の収率を最大にす るレーザー電場を設計する理論 $\left.{ }^{34)}\right)$ も開発され, 時間依存 断熱状態法や第一原理計算との融合 ${ }^{35)}$ も進んでいる. 光 反応制御を第一原理的に提案する制御理論の誕生が待ち 望まれる。

\section{参考文献}

1) K. Yamanouchi: Science 295 (2002) 1659.

2) T. Brixner and G. Gerber: Chem. Phys. 48 (2003) 418.

3) J. R. Levis, G. M. Menkir, and H. Rabitz: Science 292 (2001) 709.

4) J. Jortner and R. D. Levine: in Mode Selective Chemistry, ed. J. Jortner, R. D. Levine, and B. Pullman (Kluwer, Dordrecht, 1991) p. 535 .

5) H. Harada, M. Tanaka, M. Murakami, S. Shimizu, T. Yatsuhashi, N. Nakashima, S. Sakabe, Y. Izawa, S. Tojo, and T. Majima: J. Phys. Chem. A 107 (2003) 6580.

6) R. Itakura, J. Watanabe, A. Hishikawa, and K. Yamanouchi: J. Chem. Phys. 114 (2001) 5598.

7) L. Robson, K. W. D. Ledingham, A. D. Tasker, P. McKenna, T.
McCanny, C. Kosmidis, D. A. Jaroszynski, D. R. Jones, R. C. Issac, and S. Jamieson: Chem. Phys. Lett. 360 (2002) 382.

8) I. Kawata, H. Kono, and Y. Fujimura: J. Chem. Phys. 110 (1998) 11152.

9) H. Kono, Y. Sato, Y. Fujimura, and I. Kawata: Laser Physics 13 (2003) 883.

10) K. Harumiya, I. Kawata, H. Kono, and Y. Fujimura: J. Chem. Phys. 113 (2000) 8953.

11) K. Harumiya, H. Kono, Y. Fujimura, I. Kawata, and A. D. Bandrauk: Phys. Rev. A 66 (2002) 043403.

12) I. Kawata and H. Kono: J. Chem. Phys. 111 (1999) 9498.

13) H. Kono, Y. Sato, N. Tanaka, T. Kato, K. Nakai, S. Koseki, and Y. Fujimura: Chem. Phys. 304 (2004) 203.

14) H. Kono, Y. Sato, M. Kanno, K. Nakai, and T. Kato: Bull. Chem. Soc. Jpn. 79 (2006) 196.

15) A. D. Bandrauk and H. Kono: Molecules in Intense Laser Fields: Nonlinear Multi-Photon Spectroscopy and Near-Femtosecond to Sub-Femtosecond (Attosecond) Dynamics (Advances in Multi-Photon Processes and Spectroscopy Vol. 15, ed S. H. Lin, A. A. Villaeys, and Y. Fujimura, World Scientific, Singapore, 2003) p. 147.

16) H. Nakamura: J. Phys. Chem. A 110 (2006) 555.

17) Y. Kayanuma: Phys. Rev. A 50 (1994) 843.

18) Y. Sato, H. Kono, S. Koseki, and Y. Fujimura: J. Am. Chem. Soc. $125(2003) 8020$.

19) $|2(R, t)\rangle$ からイオン化は実験的にも証明されている。例え ば, A. Staudte, D. Pavicic, S. Chelkowski, D. Zeidler, M. Meckel, H. Niikura, M. Schöffler, S. Schössler, B. Ulrich, P. P. Rajeev, Th. Weber, T. Jahnke, D. M. Villeneuve, A. D. Bandrauk, C. L. Cocke, P. B. Corkum, and R. Dörner: Phys. Rev. Lett. 98 (2007) 073003.

20) A. Hishikawa, A. Iwamae, and K. Yamanouchi: Phys. Rev. Lett. 83 (1999) 1127.

21) R. Itakura, K. Yamanouchi, T. Tanabe, T. Okamoto, and F. Kannari: J. Chem. Phys. 119 (2003) 4179.

22) H. Yazawa, T. Tanabe, T. Okamoto, M. Yamanaka, F. Kannari, R. Itakura, and K. Yamanouchi: J. Chem. Phys. 124 (2006) 204314.

23) I. V. Hertel, T. Laarmann, and C. P. Schulz: Adv. At. Mol. Opt. Phys. 50 (2005) 219.

24) V. R. Bhardwaj, P. B. Corkum, and D.M. Rayner: Phys. Rev. Lett. 91 (2003) 203004.

25) R. Sahnoun, K. Nakai, Y. Sato, H. Kono, Y. Fujimura, and M. Tanaka: Chem. Phys. Lett. 430 (2006) 167.

26) R. Sahnoun, K. Nakai, Y. Sato, H. Kono, Y. Fujimura, and M. Tanaka: J. Chem. Phys. 125 (2006) 184306.

27) S. Díaz-Tendero, M. Alcamí, and F. Martín: Phys. Rev. Lett. 95 (2005) 013401.

28) W. Forst: Unimolecular Reactions (Cambridge, Cambridge, 2003).

29) C. Lifshitz: Int. J. Mass. Spectrom. 198 (2000) 1.

30) A. Reinköster, U. Werner, N. M. Kabachnik, and H. O. Lutz: Phys. Rev. A 64 (2001) 023201.

31) K. Nakai, H. Kono, Y. Sato, N. Niitsu, R. Sahnoun, M. Tanaka, and Y. Fujimura: Chem. Phys. 338 (2007) 127.

32) T. Laarmann, I. Shchatsinin, A. Stalmashonak, M. Boyle, N. Zhavoronkov, J. Handt, R. Schmidt, C. P. Schulz, and I.V. Hertel: Phys. Rev. Lett. 98 (2007) 058302.

33) J. Werschnik and E. K. U. Gross: J. Opt. B 7 (2205) S300.

34）藤村勇一, 大㭇 幸義：化学総説 44 「超高速化学ダイナミク スーフェムト・ピコ秒領域の化学一」(学会出版センター, 2002) p. 221.

35) G. G. Balint-Kurti, F. R. Manby, Q. H. Ren, M. Artamonov, T. S. Ho, and H. Rabitz: J. Chem. Phys. 122 (2005) 084110.

\section{レーザーワード}

非断熱遷移 (nonadiabatic transition)

系を記述する座標が2種類ある系を考える $(R$ と $r$ で代表 させる)，座標 $R$ の運動が他方 $r に$ 比べてはるかに遅い場合 には，Rを固定して $r$ に関する波動方程式を解き， $R$ を断熱 パラメータとして定義した断熱状態がRの運動を記述する 良い近似となる。 $R$ を原子間距離, $r$ を電子座標として得 られる分子の断熱ポテンシャルが最も典型的な例である
が，本稿のようにRが時間である例もある。実際には，断 熱パラメー夕Rは有限の速さで変化しているので，そのた めに断熱状態間の乗り移りがおこる。これが非断熱遷移 であり，断熱状態が互いに近ついているところ(擬似交差) で起こりやすい.

(河野裕彦) 